\title{
"The EU in its current form is a tragic mistake of the European history"
}

Russia in Global Affairs Associate Editor Glenn Diesen talks with former President of the Czech Republic Václav Klaus about the current state of affairs in the EU, populism, green politics, globalization, and other controversial issues of today.

- You are currently writing a book devoted to the 30th anniversary of the fall of communism in your country and the rest of Europe. What are the key themes in the book and the main lessons learnt from the events of 1989 ?

- I have been trying to discuss and analyze the transition from communism to a free society more or less permanently-in an effort to keep the memory of this unique historical process alive. This year's anniversary gives me a new motivation to say something about it. Thirty years since the fall of communism is already a long time, nevertheless, communism is still remembered in our part of the world as if it ended yesterday. In 1948, during the communist putsch in Czechoslovakia, no one mentioned the fact that it was just 30 years since the end of the First World War and the Austro-Hungarian Empire's collapse. Today, on the contrary, we are still discussing the communist heritage.

My book discusses neither communism, nor the events connected with its fall. It is devoted to the discussion of the post-communist

Václav Klaus is a prominent Czech economist and politician, former President of the Czech Republic (2003-2013).

Glenn Diesen, Ph.D., is a professor with the Higher School of Economics, Moscow, Russia and an associate editor of Russia in Global Affairs. 
era. This is much more relevant to our contemporary life than the events of November 1989. My book defends the 1990s, but it is very critical of the years which followed. The frustration the people like me feel now is in some respects similar to that I felt in the last years of communism. We wanted something else than today's European political, economic and social system, than today's European form of integration and the resulting loss of our sovereignty.

- I remember another anniversary, the 10th anniversary of your memorable speech in the European Parliament in 2009. Would it be correct to say that you advocate a European future for the Czech Republic, but you are critical of the direction of the EU's development? What has changed over the past decade and have your views on the EU changed? To what extent is the experience of the 1989 events relevant to the contemporary challenges in Europe?

- This speech of mine was probably the most critical speech ever made in the European Parliament. It is still valid. I wouldn't go there with a different speech now. My views have not changed, the essence of the European integration has. The "European project" has fundamentally moved from integration to unification over the last decades. This shift was mostly done by the Maastricht and the Lisbon Treaties. I consider the EU in its current form a tragic mistake of the European history. We have, however, no way out. For a small country like the Czech Republic, there is no easy Brexit, even though we know that the EU is not able to change itself.

- The political notion that is most frequently used nowadays is "populism." "Populists" are feared and blamed for everything in Europe and in the U.S. What is your perception of this phenomenon? How do you understand “populism?" Do you see it as a real threat to democracy, as liberal critics describe it?

- I am not sure that populism is the most frequent political term, perhaps it is in some circles. I don't like this term and for that reason I never use it. I don't think it is a threat to democracy. Populism has become a political label, a political insult these days. It is used for 
attacking those who disagree with the current European integration and who dare criticize the policies of European and American elites. The real threat to democracy is the caricature of democracy, fashionably called "liberal democracy." It is neither liberal, nor democratic.

- Whom of contemporary statesmen would you describe as likeminded with you? What do you think of such leaders as Donald Trump, Vladimir Putin, Boris Johnson, Emmanuel Macron, Viktor Orbán?

- The five names you selected make up a very mixed and nonhomogeneous group of people. I would say I am in the same boat with Trump, Putin and Orbán-we are all in favor of a nation state (against all kinds of international organizations). These three politicians may be different in many other respects but this one I consider a crucial one. They are not "globalists." Emmanuel Macron is definitely on the other side of the political and ideological barricade, he is a leading globalist of the current era. I am very much afraid of his policies. And Boris Johnson has still to prove that he is able to achieve something.

- Is ideological rivalry over? If we speak about ideology, it seems that the classical ways of thinking that were characteristic of the 19th and 20th centuries are eroding and losing public support. "Peoples' parties" are declining everywhere. What kind of worldview has a future?

- The fight between socialism (or perhaps communism) and capitalism is over. But ideological rivalry continues. The new ideological disputes are no less severe. The political parties and their ideologies have, however, changed. I see as the main danger the currently victorious ideologies of genderism, feminism, multiculturalism, humanrightism, environmentalism, transnationalism, and globalism. I am very critical-including in my book-of them. All of them belong to the left side of politics, but the main allegedly right-of-center political parties are accepting many of their arguments. I am afraid that we-the old-fashioned democrats-are on the losing side. 
- Is globalization in reverse?

- Definitely not. It continues and will go forwards. We shouldn't interpret the disputes between the U.S. and China as deglobalization. Globalization (or better to say the internationalization of economic activities) is a positive phenomenon. The problem is different, it is called globalism, that is, attempts to suppress nation states and deprive them of their sovereignty and independence. Nation states should start defining the rules of globalization. Not everything should be allowed. Total opening up of individual countries is not a rational behavior, we should have clearly defined principles that would guarantee the coherence of individual nation states.

- You are known as a staunch critic of climate change concepts. Meanwhile the "green wave" in politics is being boosted by the apparent worsening of climate in Europe and elsewhere, and increased turbulence in nature. What should people faced with climate change do? And why do you think measures proposed by the Greens are wrong?

- I don't think the weather in Europe is "constantly worsening." I am not aware of anything like that, the data do not show it. To say that the weather is worsening is an empty phrase propagated by all kinds of Greens (not just by Green political parties but by the Greens in all political parties). The current climate in Europe is not a problem. The problem is our fighting the climate, a hopeless, democracy-suppressing and economy-undermining behavior.

- Russia's grievances with Europe after the fall of communism have focused on the absence of post-Cold War settlement accommodating Russia on the continent. How do you see the future of the relations between Russia and Europe? Does the nascent strategic partnership between Russia and China offer opportunities and/or challenges for Europe?

- The question has three aspects:

First, I don't believe it should be called "Russia's grievances." Any plans for a post-Cold War European "settlement" have been rather 
exercises in "wishful thinking" than real projects. They have never been realistic and meaningful concepts. We saw it as a continuation of Gorbachev's naive concept of a "Common European Home." No one in Western or Central Europe was interested in it at that time. That said, I do not imply that I accept the current very dangerous and unfair demonization of Russia by the West. This policy, or perhaps this ersatz of policy, threatens to become a problem.

Second, the passive extrapolation of current trends and tendencies in relations between Europe and Russia suggests new Cold War era outcomes. This is something which must be avoided.

I have a problem using the term 'Europe' in our discussions. Europe is not the doer of history and of international relations, Europe doesn't "behave." We should try to convince the European nation states to start thinking differently, not "continentally." They should accept that Russia is a country with its authentic national interests.

And, third, the strategic partnership between Russia and China is only a hypothetical project of the future. I don't see it now, not even in its "nascent" form. It seems to me that China is not interested in it. China wants a G2 arrangement with the U.S., not a G3 version (including Russia). 